\title{
Bilişim Teknolojileri ve Yazılım Dersi Öğretmenlerinin Kodlama Eğitimine Yönelik Görüşleri*
}

\section{Information Technology and Software Course Teachers' Opinions on Computing Education}

\author{
Aslı GÖNCÜ**, İbrahim ÇETİN***, Polat ŞENDURUR****
}

\begin{abstract}
Öz: Öğretmenler sınıf içerisinde tasarlanan programları uygularlar. Öğretmenlerin alan ve/veya o alanın öğretimine yönelik görüşleri programın uygulanma şeklinde belirleyici olabilir. Dolayısı ile öğretmenlerin görüşleri dersin işlenişine yönelik önemli ipuçları verebilir. Bu çalışmanın amacı bilişim teknolojileri ve yazılım dersi öğretmenlerinin kodlama eğitimine yönelik görüşlerini keşfetmektir. Bu çalışmada durum çalışması deseni kullanılmıştır. Çalışmanın katılımcılarını Batı Karadeniz Bölgesindeki bir ilden yirmi iki öğretmen oluşturmaktadır. Araştırmacılar tarafindan oluşturulmuş yarı yapılandırılmış görüş̧me formu vasıtasıyla katılımcılardan nitel veri toplanılmıştır. Görüşmeler sonucunda öğretmenlerin kodlama eğitimine yönelik olarak teknolojik, pedagojik ve alan bilgisi açısından çeşitli eksikliklerinin olduğu anlaşılmıştır. Öğretmenlerin blok tabanlı kodlama ortamlarına görece olarak daha hâkim oldukları fakat diğer ortamlara yeteri kadar hâkim olmadıkları görülmüștür. Öğretmenlerin ve öğretmen adaylarının eksikliklerinin giderilmesi için çeşitli önerilerde bulunulmuştur.
\end{abstract}

Anahtar Kelimeler: Kodlama eğitimi, bilişim teknolojileri ve yazılım dersi, öğretmen görüşü, durum çalışması

\begin{abstract}
Teachers implement curriculums in the classroom. Teachers' views related to a subject and teaching of the subject can have an effect on the way the program is implemented. Therefore, the opinions of the teachers can give important clues about their implementation. The aim of this study was to explore the opinions of information technology and software course teachers on computing education. Case study design was utilized in this research. Participants of the study was selected from a city in the Western Black Sea region in Turkey. Qualitative data were gathered through a semi-structured interview protocol that was formed by researchers. As a result of the interviews, it was found that teachers had various difficulties regarding computing education in terms of technological, pedagogical and content knowledge. While teachers were relatively more knowledgeable in block-based coding environments, it was found that they were not good enough in other environments. Various suggestions have been made to address the difficulties of teachers.
\end{abstract}

Keywords: Computing education, information technology and software course, teacher opinions, case study

\section{Giriş}

Bir taraftan bilgisayar bilimi eğitimi günümüz okullarında yaygınlaşırken diğer taraftan bilgisayar bilimleri ile ilgili kavramların öğrenilmesi ile ilgili öğrencilerin yaşadıkları öğrenme zorlukları ile ilgili araştırmalar alanyazında yerini almaktadır (Cetin, 2013; Denner, Werner ve Ortiz, 2012; Du Boulay, 1986; Robins, Rountree ve Rountree, 2003). Kodlama eğitimlerinin başarılı olabilmesi için öğretmenlerin bilgi ve becerileri önemlidir. Farklı programlama ortamlarına aşina olma, robotlar gibi programlamanın fiziksel çıktılarının gözlemlenebileceği araçları kullanabilme öğretmenlerden beklenen beceriler arasından yer almaktadır. Ayrıca bilgisayarsız bilgisayar

\footnotetext{
*Bu çalışma birinci yazarın yüksek lisans tezinden üretilmiştir.

** Öğretmen, Ufuk Üniversitesi, Meslek Yüksek Okulu, Ankara-Türkiye, ORCID: 0000-0003-1696-5248, e-posta: goncuasl@gmail.com

*** Doç. Dr., Bolu Abant İzzet Baysal Üniversitesi, Eğitim Fakültesi, Bolu-Türkiye, ORCID: 0000-0001-5127-0471, e-posta: ibretin@hotmail.com

**** Dr. Öğr. Üyesi, Samsun Ondokuz Mayıs Üniversitesi, Eğitim Fakültesi, Samsun-Türkiye, ORCID: 0000-00032225-2359, e-posta: polat.sendurur@omu.edu.tr
} 
bilimi etkinlikleri oluşturma ya da var olan etkinlikleri uyarlama öğretmenlerin sahip olması gereken özelliklerdendir (Kalelioğlu ve Keskinkılıç, 2017).

Genel bir bakış açısıyla öğrencilerin bilgi işlemsel düşünme becerilerini geliştirmeye yönelik öğrenme ortamlarını oluşturmak için öğretmen ve öğretmen adaylarının alan bilgisine ve bu bilgiyi öğrencilerin oluşturmasına yardımcı olmak adına pedagojik bilgiye gereksinimini bulunmaktadır. Shulman (1986) pedagoji bilgisi ile alan bilgisi arasındaki ilişkiyi, bir öğretmenin kendi alanındaki konuyu aktarırken; bu bilgiyi öğrencilere nasıl öğretebileceği hakkındaki bilgisini öne çıkarmakta ve bu bilginin yalnızca bilgiye hâkim olmaktan daha önemli olduğunu dile getirerek açıklamıştır. Shulman tarafından Pedagojik Alan Bilgisi (PAB) olarak adlandırılan bu yapı konunun en etkili şekilde öğretimini sağlayacak yöntem, teknik ve stratejileri bilmekle ilgilidir.

Koehler ve Mishra (2008) teknolojinin eğitim bir parçası olması gerektiğini savunarak teknoloji bilgisinin de PAB'a eklenilmesi gerektiğini ileri sürmüştür. Teknolojinin pedagojiden ve alan bilgisinden bağımsız bir şekilde eğitim ile bütünleştirilemeyeceği anlaşılmış ve Shulman'ın (1986) PAB modeline teknoloji bilgisinin eklenilmesi ile Teknolojik Pedagojik Alan Bilgisi (TPAB) modeli ortaya çıkmıştır (Graham ve diğerleri, 2009; Koehler ve Mishra, 2008). TPAB yaklaşımında teknoloji, pedagoji ve alan bilgisi ayrık olarak düşünülmez aksine TPAB bu üçünün kesişiminde bulunur. Kodlama eğitimi alanyazını (Gülbahar, 2017; Şimşek, 2018) incelendiğinde iki temel başlık kodlama eğitimi için ön plana çıkmaktadır. Bunlar bilgi işlemsel düşünmenin kavramsal çerçevesi ve öğrencilerin bilgisayar bilimini veya kodlamayı öğrenmesi için oluşturulacak öğretim ortamlarında kullanılacak yaklaşımlardır.

Bilgi işlemsel düşünme terimini kodlama eğitimi bağlamında ilk kullanan Seymour Papert (Papert ve Harel, 1991) olmasına rağmen bilgi işlemsel düşünmenin tanımını ilk defa Wing (2006) yapmıştır. Wing'e (2006) göre "bilgi işlemsel düşünme, bilgisayar biliminin kavramlarını kullanarak problem çözme, insan davranışlarını anlama ve sistem tasarlama üzerinde durur" (s. 33). Wing (2006) aynı zamanda bilgi işlemsel düşünmenin sadece bilgisayar bilimcileri tarafindan değil herkes tarafından bilinmesi gerektiğini söylemiş ve buna ek olarak çocukların okuma, yazma, aritmetik gibi analitik becerilerinin yanına bilgi işlemsel düşünmenin de eklenilmesi gerektiğini savunmuştur. Daha sonra Wing bilgi işlemsel düşünmeyi Cuny ve Snyder ile birlikte yeniden tanımlamıştır. Bu tanıma göre bilgi işlemsel düşünme "çözümlerin bir bilgi işleme birimi tarafindan etkili şekilde yerine getirilebilecek formda sunulması amaciyla problemleri ve çözümleri formülleştirmeyi içeren düşünme sürecidir" (Cuny, Wing ve Snyder' dan aktaren Wing, 2011, s. 20). Bu tanımlara ek olarak Brennan ve Resnick (2012) bilgi işlemsel düşünmeyi üç boyutlu bir şekilde ele almıştır. Buna göre bilgi işlemsel düşünme bilgi işlemsel kavramlar (programlama için kullanılan kavramlar), bilgi işlemsel uygulamalar (programcının problem çözme esnasında başvurduğu/oluşturduğu pratikler) ve bilgi işlemsel bakış açıları (uygulamalar üzerine düşünme ile farklı bakış açıları oluşturmak) olmak üzere üç başlıktan oluşur.

Bilgi işlemsel düşünmeyi teorik olarak tanımlamak onun temel çerçevesini belirlemede yardımcı olur. Fakat bu tanım doğrudan eğitimcilere sınıf içi uygulamalar hakkında yeterli bir bilgi bütünü vermez. ISTE (International Society for Technology in Education) ve CSTA (Computer Science Teacher Association) birlikte çalışarak bilgi işlemsel düşünmenin operasyonel tanımını oluşturmuştur (ISTE, 2011). Bu tanıma bilgi göre bilgi işlemsel düşünme problem çözme sürecidir. Bu problem çözme süreci aşağıdaki maddeleri içerir (ISTE, 2011):

1. Problemleri, bilgisayar veya diğer araçlarla çözmeye yönelik olarak formüle etme,

2. Veriyi mantıksal olarak organize ve analiz etme,

3. Veriyi model ve simülasyonlar gibi soyutlamalar vasitasiyla temsil etme,

4. Algoritmik düşünme vasitasıyla çözümleri otomatikleştirme,

5. En verimli olacak şekilde olası çözümleri tanımlayıp, analiz edip onları uygulama,

6. Bu problem çözme sürecini çok çeşitli problemlerin çözümü için genelleme ve transfer etme.

Alanyazın incelendiğinde bilgi işlemsel düşünme üzerine tam bir anlam birliği oluşmadığı görülür. Fakat bilgi işlemsel düşünmenin farklı tanımları göz önüne alındığında bu tanımlarda temel olarak şu altı bileşenin bulunduğu görülür: (i) problem çözme, (ii) problemleri 
bileşenlerine ayırma, (iii) soyutlama, (iv) algoritmik düşünme, (v) algoritmanın değerlendirilmesi ve (vi) algoritmanın genelleşmesi (Aho, 2012; Kalelioğlu, Gülbahar ve Kukul, 2016; Selby ve Wollard, 2013; Wing, 2006). Her bir bileşen hakkında önemli miktarda araştırmalar yapılmıştır ve bilişim teknolojileri ve yazılım öğretmenleri ve öğretmen adayları tarafından bilinmelidir.

Bahsedildiği gibi kodlama eğitimindeki ikinci önemli başlık öğretim yaklaşımlarıdır. $\mathrm{Bu}$ yaklaşımlar oyun tabanlı öğrenme ve proje tabanlı öğrenme gibi diğer öğretim alanları ile ortak olarak paylaşılabilecek yaklaşımlar olabileceği kodlama eğitimine özgün araçlı odaklı yaklaşımlar da olabilir. Bu makalenin çerçevesinden ötürü burada araç odaklı yaklaşımlardan bahsedilecektir. Alanyazın genel bir çerçeveden incelendiğinde öğretmenlerin sahip olması gereken dört temel araç odaklı yaklaşım bulunmaktadır. İlk araç odaklı yaklaşıma bilgisayarsız bilgisayar bilimi ismi verilmiştir. İkinci yaklaşım robot tabanlı kodlama olarak adlandırılmıştır. İkinci yaklaşımda görsel programlama yapılmaktadır ve blok tabanlı kodlama olarak adlandırılmıştır. Son yaklaşım ise metin tabanlı kodlamadır. Bunlara ek olarak bahsi geçen yaklaşımlar birleştirilerek hibrit ortamlarda kodlama da yaptırılabilir (Kert, 2018).

Adından da anlaşılacağı üzere bilgisayarsız bilgisayar bilimi yaklaşımında bilgisayarlar kullanılmaz (Kalelioğlu, 2017). Öğrencilerin karmaşık kodlama kavramlarını anlamlandırması veya zor kodlama problemlerini çözmesi için doğrudan programlama ortamlarını kullanması öğrenciler için her zaman verimli olmayabilir (Bell, Alexander, Freeman ve Grimley, 2009). Programlama dilinin getirdiği zorluklar öğrencilere ek yükler getirebilir ve öğrenmesini zorlaştırabilir. $\mathrm{Bu}$ gibi durumlarda bilgisayarsız bilgisayar bilimi etkinlikleri kullanılabilir. Bilgisayarsız bilgisayar biliminde fiziksel oyun etkinlikleri ve çeşitli materyaller kullanılarak etkinlikler yapilabilir.

Kodlama eğitimindeki bir diğer yaklaşım robot tabanlı programlamadır. Robot tabanlı programlamada çevresinden gelen çeşitli veriyi algılayabilen, bu veriyi yorumlayıp bu çerçevede tepkiler üretebilen robotlar kullanılır (Üçgül, 2017). Bu yaklaşımın diğer yaklaşımlardan farkı kodlanan cihazın öğrencinin fiziksel çevresinde olmasıdır. Öğrenciler yazdığı programların etkisini fiziksel olarak gözlemleyip yazdığı kodları somut olarak değerlendirebilir. Farklı araştırmacılar tarafından farklı şekillerde kullanılmış olmasına rağmen robot tabanlı programlamanın öğretimsel ilk örnekleri inşacılık (constructionism) içerisinde hayat bulmuştur (Harel ve Papert, 1990).

Blok tabanlı öğretim ortamlarında sürükle bırak özelliğine sahip kod blokları bulunmaktadır (Yükseltürk ve Altık, 2017). Program yazmak için bu kodlar sürüklenerek kodlama alanına bırakılır. Bu yaklaşımda öğrenciler dilin sözdizimi ile ilgili bilgiler ile uğraşmadan kodlama yapabilmektedir. Öğrenciler kodları sürükleyip birbirine bağlayarak deneme yanılma yöntemiyle de kod yazabilir. $\mathrm{Bu}$ yaklaşımda öğrenciler problem çözme ve planlama gibi kodlamanın üst seviye bileşenleri ile daha fazla ilgilenecek vakit bulabilir.

Metin tabanlı yaklaşım bu yaklaşımlar arasından en eski olandır (Kandemir, 2017). Bu yaklaşımda metin tabanlı bir kodlama ortamı kullanılır. Öğrenciler kodlama dilinin söz dizimini ve bu söz dizimiyle ilgili kuramsal yapıyı bilmek durumundadır. Bu gereklilik öğrencilere ek bilişsel yükler getirebilir. Yeni başlayanların anlamlı kodlar üretmesi zaman gerektirir. Fakat metin tabanlı ortamların kütüphaneleri oldukça gelişmiştir ve ileri seviye programlama için elverişli bir ortam sunar.

Bilgisayar bilimi eğitimi birçok ülkenin müfredatına veya standartlarına zorunlu veya seçmeli ders olarak girmiş̧tir. Bu değişimlere paralel olarak kodlama eğitimi ülkemizde ortaokul ve lise seviyesindeki okullarda zorunlu ve seçmeli ders olarak verilmektedir. Kodlama eğitimindeki bu değişikliklerin başarılı olmasında öğretmenlerin önemli bir rol oynayacağ 1 düşünülmektedir. $\mathrm{Bu}$ konu ile ilgili son zamanlarda sınırlı da olsa yeni çalışmalar yapılmaktadır (Menekse, 2015; Yecan, Özçınar ve Tanyeri, 2017). Yapılan çalışmalar öğretmenlerin alan bilgilerinde ve bu alan bilgisini sınıflarda öğretim için kullanmak üzere gerekli olan pedagojik bilgilerinde sinırlılıkların olduğunu göstermektedir (Menekse, 2015; Türker ve Pala, 2018). Bu konu ile ilgili yeni çalışmaların yapılmasına ihtiyaç vardır (Yadav, Krist, Good ve Caeli, 2018; Yecan, Özçınar ve Tanyeri, 2017). Öğretmenlerin kodlama eğitimi açısından güncel durumlarının ortaya konulması kodlama eğitiminin kalitesi açısından önemlidir. Sonuç olarak, bu çalışmanın amacı bilişim 
teknolojileri ve yazılım dersi öğretmenlerinin kodlama eğitimine yönelik görüş ve düşüncelerini araştırmaktır.

\section{Yöntem}

Bu çalışmada nitel araştırma yöntemleri kullanılmıştır. Nitel araştırma yöntemleri bir olayın, durumun veya olgunun derinlemesine incelenmesini içerir (Yıldırım ve Şimşek, 2013). Bu çalışmada durum çalışması kullanılmıştır. Durum çalışması günümüze ait bir olayın gerçek yaşam bağlamı içerisinde incelendiği ampirik bir sorgulamadır ve durum çalışmasında olgu ile bağlam arasındaki sınırlar tam olarak belirgin değildir (Yin, 2003). Durum çalışmasında sınırları belirli bir olgu tanımlanır ve bu olgu derinlemesine incelenir. Bu tip bir çalışmada genelleme temel hedefler arasında olmamasına rağmen diğer araştırmacılar veya uygulayıcılar durum çalışmasının sonuçlarını kendi amaçları doğrultusunda kullanabilir (Ersoy, 2016).

Nitel araştırma yöntemlerinin kullanıldığı çalışmanın etik ilkelere uygunluğunun belgelenmesi amaciyla Abant İzzet Baysal Üniversitesi Sosyal Bilimlerde İnsan Araştırmaları Etik Kurulu'na başvurulmuştur. İlgili kurula 2016/146 protokol numarası ile yapılan başvuru, kurulun 14.11.2016 tarihli ve 2016/06 toplantısında değerlendirilerek etik olarak uygun bulunmuştur (Say1: 12050492-605-E.14453702, Konu: Araştırma izni-Aslı Göncü). Ayrıca çalışma kapsamında görüşme gerçekleştirilen katılımcılara bilgilendirilmiş gönüllü olur/onam formu imzalatılmıştır. Tüm bilgiler ışığında çalışma süresince Makalelerde Araştırma ve Yayın Etiğine uyulmuştur.

\section{Örneklem/çalışma grubu}

Araştırmanın katılımcılarını Batı Karadeniz bölgesindeki bir şehirdeki merkez ve ilçelerinden 22 bilişim teknolojileri ve yazılım dersi öğretmeni oluşturmaktadır. Katılımcı belirleme sürecinde seçiminde birden fazla yöntem kullanılmıştır. Kolay ulaşılabilir durum örneklemesi bunlardan ilkidir. Araştırmacıların bu ildeki öğretmenlere ulaşımı kolay olduğu için araştırmacının katılımcıları Batı Karadeniz bölgesinden seçilmiştir. İkinci olarak araştırma kapsamında maksimum çeşitliliği sağlamak üzere bu ilin bütün ilçelerine ulaşmak hedeflenmiştir. Maksimum çeşitliliğin kullanılmasındaki amaç çeşitliliği sağlayarak araştırılan duruma genelleme yapmak değil, aksine çeşitlilik gösteren durumlar arasındaki ortaklık veya benzerlikleri maksimum derecede yansıtmaktır (Yıldırım ve Şimşek, 2013). Üçüncü olarak katılımcıların hâlihazırda bilişim teknolojileri ve yazılım dersine giriyor olmaları kıstas olarak belirlenmiştir. Burada amaç dersi veren öğretmenlerin gözünden kodlama eğitimini ortaya koymaktır. Sonuç olarak bu koşullara uyan öğretmenlerden gönüllü olanlar araştırmaya katılmıştır. Gönüllü katılım esasına ve maksimum çeşitlilik sağlanmaya çalışılması nedeniyle toplam katılımcı sayısı 22 ile sınırlı kalmıştır.

Katılımcıların on dokuzu Bilgisayar ve Öğretim Teknolojileri Eğitimi bölümünden mezun olmuştur. Bir katılımcı Görsel Sanatlar bölümünden, diğer bir katılımcı Sanat Öğretmenliği bölümünden ve son katılımcı ise Aile Ekonomisi ve Beslenme Öğretmenliği bölümünden mezun olmuştur. Yirmi iki katılımcıdan on beşi erkek iken yedisi kadındır. Dokuz katılımc1 1-5 yıl arası tecrübeye, on katılımc1 6-10 yıl arası tecrübeye, üç katılımcı ise 11 ve üstü yıl tecrübeye sahiptir. Katılımcıların cinsiyet ve mesleki tecrübe açısından dağılımı Tablo 1'de verilmiştir.

Tablo 1.

Katılımcıların demografik özellikleri

\begin{tabular}{cccccccccc}
\hline & \multicolumn{2}{c}{ Cinsiyet } & & \multicolumn{3}{c}{ K1dem } & & \multicolumn{2}{c}{ Mezuniyet } \\
\cline { 2 - 3 } \cline { 9 - 10 } & Kadın & Erkek & & $1-5$ Y11 & $5-10$ Y11 & 10 ve Üstü nn & & BÖTE & Diğer \\
\hline $\mathrm{N}$ & 7 & 15 & & 9 & 10 & 3 & & 19 & 3 \\
$\%$ & 30 & 70 & & 41 & 45 & 14 & & 86 & 14 \\
\hline
\end{tabular}




\section{Veri toplama ve analiz süreci}

Öğretmenlerin kodlama eğitimine yönelik görüşlerini ortaya çıkarmak amacıyla araştırmacılar tarafından 10 sorudan oluşan yarı yapılandırılmış bir görüşme formu oluşturulmuştur. Görüşme formunun oluşturulması üç aşamayı içerir. Bunlar araştırmacılar tarafından soruların oluşturulması, ilk pilot çalışma ile soruların değerlendirilmesi ve ikinci pilot çalışması ile alan uzmanlarıla beraber görüşme formuna son halinin verilmesidir. Yarı yapılandırılmış görüşme formundaki sorular oluşturulurken temel olarak iki farklı kaynaktan yararlanılmıştır. Bunlar alanyazın taraması ile ulaşılan ve araştırmacıların kendileri tarafından oluşturduğu sorulardır. Sorular hazırlanırken soruların açık, anlaşılır ve yönlendirmeye mahal vermeyen nitelikte olmasına özen gösterilmiştir. Görüşme formunun ilk hali ile 8 gönüllü bilişi̇im teknolojileri ve yazılım dersi öğretmen adayı ile pilot görüşmeler yapılmıştır. Bu görüşmeler ışı̆̆ı̆nda görüşme formu üzerinde gerekli değişiklikler yapılmıştır. Bunun ardından bir bilişim teknolojileri ve yazılım dersi öğretmeni ile ikinci pilot görüşme yapılmıştır. Yapılan görüşme ve görüşme formu araştırmacılar ve Bilgisayar ve Öğretim Teknolojileri Eğitimi bölümünden bir alan uzmanı tarafından değerlendirilmiştir. Bunun sonucunda görüşme formuna son hali verilmiştir. $\mathrm{Bu}$ süreçte gerekli etik izin ve kurum izni alınarak gönüllü olan öğretmenler ile çalışılmıştır. Görüş̧e formunun tamamlanmasının ardından belirlenen 22 katılımcı ile görüşmelere başlanılmıştır. Her bir katılımcı ile yapılan görüşme ortalama 15 dakika kadar sürmüştür. Görüşmeler ses kayıt cihazı vasıtası ile kayıt altına alınmıştır. Kayıt altına alınan görüşmeler yazılı dökümleri çıkarılarak deşifre edilmiştir.

Toplanılan veriler nitel içerik analizi kullanılarak analiz edilmiştir. Nitel içerik analizi verilerin derinlemesine çözümlenmesine olanak sağlamaktadır (Çetin, 2016; Yıldırım ve Şimşek, 2013). Bu araştırmada Schereier'in (2012) önerdiği 8 adımdan oluşan veri analizi yöntemi temel alınmıştır. Bu adımlar (i) araştırma probleminin belirlenmesi, (ii) analizi yapılacak verinin seçimi, (iii) kodlama şemasının oluşturulması, (iv) verinin bölümlere ayrılması, (v) kodlama şemasının denenmesi, (vi) kodlama şemasının değerlendirilmesi ve gerekli değişikliklerin yapılması, (vii) kodlamanın yapılması ve (viii) bulguların yorumlanıp sunulmasıdır. Araştırmacılar verinin tamamını birlikte kodlamışlardır. Kodlayıcılar arasında uyumsuzluk yaşandığında araştırmacılar aralarında tartışarak uyumsuzluk giderilmiştir.

\section{Bulgular \\ Kodlamanın amacı}

Katılımcılar ile yapılan görüşmeler sonucunda elde edilen veri analiz edildiğinde kodlama eğitiminin amacına yönelik iş yaşamı kaynaklı, düşünme becerileri, öğretim kaynaklı, üretici olma ve diğer olmak üzere beş farklı kategori elde edilmiştir. Bu kategoriler ve alt kategorileri ile ilgili bilgilere Tablo 2'den ulaşılabilir.

Tablo 2.

Kodlamanın amacina ait Kategoriler (katılımc1 sayıs1)

\begin{tabular}{|c|c|c|}
\hline $\begin{array}{l}\text { Ana Başlık } \\
\text { Kodlamanın amacı }\end{array}$ & Kategori & Alt Kategori \\
\hline \multirow[t]{5}{*}{ Kodlamanın amac1 } & İş Yaşamı Kaynaklı & $\begin{array}{l}\text { Yazilımcı yetiştirmek (6) } \\
\text { Bilişim çağ için bireyler yetiştirmek } \\
\text { (6) } \\
\text { İstihdam (2) }\end{array}$ \\
\hline & Düşünme becerileri & $\begin{array}{l}\text { Günlük yaşam problemleri (4) } \\
\text { Analitik düşünme (4 katılımcı) } \\
\text { Yaratıc1lı (3 katılımcı) } \\
\text { Çözüm Şemaları (2 katılımcı) }\end{array}$ \\
\hline & Öğretim kaynaklı & $\begin{array}{l}\text { Otantik öğrenme (5 katılımc1) } \\
\text { Öğretim teknolojisi (2 katılımcı) }\end{array}$ \\
\hline & Üretici olma & (6) \\
\hline & Diğer & (9) \\
\hline
\end{tabular}


Birinci kategori olan iş yaşamı kaynaklı kategorisi altında kodlama eğitiminin amacını iş yaşamı kaynaklı sebeplere dayandıran 14 katılımeı bulunmaktadır. Bu kategori altında yazılımcı yetiştirmek, bilişim çağ 1 için bireyler yetiştirmek ve istihdam olmak üzere üç alt kategori bulunmaktadır. Yazılımcı yetiştirmek alt kategorisinde, genel olarak yerli yazılımlar ile teknolojik araçlar üreterek ülke gelişimine katkıda bulunması hedefi için kodlama eğitiminin amacının yazılım geliştirebilen bireyler yetiştirmek olduğu öne sürülmektedir. Bu alt kategori altında 6 katılımcı bulunmaktadır. Yazılımcı yetiştirmek alt kategorisi için aşağıdaki alıntı örnek olarak verilebilir.

"Bunu zaten görüyoruz şu anda ülkemize de artı tamamen yerli teknolojik araçlara dönüş var. Bunu bir firsat olarak görmeliyiz. Bunu ögrencilerimize şimdiki okullarımızda okuyan ögrencilerimize ilkokul, ortaokul, lise onlara bunu aktarabilirsek onlarla ilerde bizim ülkemiz için daha iyi ve yerli ve milli yazılımları, teknolojik araçları gelişstirebileceklerdir." Ö15

Bilişim çağı için bireyler yetiştirmek alt kategorisi altında altı katılımcı bulunmaktadır. $\mathrm{Bu}$ katılımcılar genel olarak bulunduğumuz yüzyıldaki mesleklerin doğrudan yazılım ile ilgili olmasa bile yazılım bilgisi gerektirdiği ve üretici bir toplum için çağımızda yazılım bilgisine ihtiyaç olduğunu vurguladıkları görülmektedir. İş yaşamı kaynaklı kategorisinin son alt kategorisi olan istihdam alt kategorisinde ise iki katılımcı bulunmaktadır. Bu katılımcılar kodlamanın iş olanakları sağladığını düşündüklerini belirtmiştir. Kodlamanın sağladığı iş olanakları sayesinde bireyler daha kaliteli bir yaşama sahip olabileceklerini vurgulamışlardır.

Kodlamanın amacı başlığı altında bulunan ikinci kategori olan düşünme becerilerinde 13 katılımcı bulunmaktadır. Bu katılımcılar kodlama eğitiminin amacının öğrencilerin çeşitli düşünme becerilerini geliştirmesi olduğunu düşünmektedir. Bu kategori altında günlük yaşam problemleri, analitik düşünme, yaratıcılık ve çözüm şemaları alt kategorileri bulunmaktadır. Günlük yaşam problemleri alt kategorisinde toplamda dört katılımcı bulunmaktadır. Bu katılımcilar kodlama eğitiminin öğrencilerin algoritmik ve çok yönlü düşünme becerilerini geliştireceğini ve bu sayede günlük yaşam problemlerini çözmede daha başarılı olacaklarını düşünmektedir. Aşağıdaki alıntı bu alt kategoriye örnek olarak verilebilir.

"Burada dediğim gibi ögrencileri tamamen bir yazılımcı olarak değil, öğrenci kodlama eğitimini aldiktan sonra günlük hayatta da kullansin istiyorum. Yani şimdi kodlama eğitimine başlamadan önce bir kere algoritma yapısını veriyorsun bir kere çocuğa yani bir problem var bu problemi nasıl çözebiliriz? Diye bir işlem basamakları istiyorsunuz. Bunu günlük hayata çevirelim. Günlük hayatta çocuk bir problemle karşılaştı̆̆ında bunu entegre edebilir oraya." Ö14

Düşünme becerileri kategorisindeki ikinci alt kategori analitik düşünme ve üçüncü alt kategori ise yaratıcılık olarak isimlendirilmiştir. Analitik düşünme alt kategorisinde dört katılımcı bulunmaktadır. Bu katılımcılar kodlama eğitiminin amacının öğrencilerin analitik düşünme becerisini geliştirmek olduğunu düşünmektedir. Benzer şekilde yaratıcılık alt kategorisinde üç katılımcı bulunmaktadır. Bu katılımcılar ise kodlama eğitiminin amacının yaratıcı düşünme becerisini geliştirmek olduğunu düşünmektedir. Her iki alt kategoride bulunan katılımcılar da kısa cümleler kurmuşlardır. Buna ek olarak onların analitik düşünme ve yaratıcılıktan neyi kast ettikleri tam olarak açık değildir. Aşağıdaki iki alıntı sırasıyla bu iki kategoriye örnek olarak verilebilir.

“Kodlama neden verilmelidir, çocukların analitik düşünmesini gelişstirmek amacı ile.” Ö3

“Yani yaratıcılıklarını geliştireceğini düşünüyorum ben.” Ö19 
Bu kategorinin son alt kategorisi olan çözüm şemasında iki katılımcı bulunmaktadır. Bu alt kategoriyi oluşturan katılımcılar kodlama eğitiminin amacının öğrencilerin bir problemin birden fazla çözümünün olabileceğini görmesi gerektiğini belirtmiştir. Öğrenciler bu çözüm yollarından en uygununu seçip karşılaştıkları problemleri çözebilmelidirler.

Kodlamanın amacı başlığındaki bir diğer kategori ise öğretim kaynaklı olarak isimlendirilmiştir. Bu kategori altında yedi katılımcı bulunmaktadır. Bu katılımcılar kodlamanın amacını öğretim temelli sebeplere dayandırmıştır. Bu kategori altında otantik öğrenme ve öğretim teknolojisi olmak üzere iki alt kategori bulunmaktadır. Otantik öğrenme alt kategorisinde bulunan beş katılımcı kodlama eğitiminin önceki bilgi birikimlerinden, günlük yaşam bağlamından ve günlük yaşam ile ilişkisinden koparılmadan verilmesi gerektiğini belirtmiştir. Öğretim teknolojisi alt kategorisinde ise iki katılımcı bulunmaktadır. Bu katılımcılar temel olarak kodlamanın sadece kodlama dersinde değil diğer dersler bağlamında da kullanabileceğini belirtmektedir. Aşağıdaki alıntı otantik öğrenme alt kategorisine örnek olarak verilebilir.

“... en başta sordukları soru bu oluyor. Hani biz bu kodlamayı öğrendik te nerde kullanacağız? Bir öğretmensiniz şu anda bir Fatih projesi var burada mesela nedir kodlamayı bildiğin anda kendi dersinle ilgili bir tane proje geliştirebilir onu sunabilirsin veya bir tane animasyon oluşturup dersi zevkli hale getirebilirsiniz. " Ö3

Kodlamanın amacı başlığı altındaki sıradaki kategori üretici olma olarak isimlendirilmiştir ve bu kategori altında altı katılımc1 bulunmaktadır. Bu alt kategoride bulunan katılımcılar öğrencilerin üretken bireyler olarak yetiştirilmesi gerektiğini savunmaktadır. Katılımcılara göre öğrenciler üretirken özgüven kazanacaktır ve gelecekte üretici bireyler olarak ülke ekonomisine katkı sağlayacaktır. Aşağıdaki alıntı üretici olma kategorisine örnek olarak verilebilir.

“... çocukların bir şeyler üretip üretebildiğini fark etmesi lazım ki sonrası gelsin. Hep zaten bakıyoruz dünyanın en zengin şirketleri kimler yani bilgisayar sektörünün içinde olan şirketler, Bill Gates yani bunların hepsi bakıyoruz niye hep çünkü onlar programlamayı artık oturtturmuşlar. Bunlar kazandı bunlar gidiyor. Ders anlatırken de diyorum ki hiç araştırıyor musunuz diyorum en zengin şirketler kimler ne yapıyor bunlar kim hayatlarından örnek verin diyorum baklyorlar gerçekten diyorum ki sizin de ögrenmeniz lazım sizin de bir şeyler üretmeniz lazım, tüketmeyi bırakalım artık diyorum ya. Tüketme aşamasını bir geçelim diyorum..." Ö13

Son olarak, diğer kategorisinde konuyla doğrudan bağlantısı bulunmayan ve/veya az frekanslı yanıtlar bulunmaktadır. Diğer kategorisini dokuz katılımcı oluşturmuştur. Bu araştırmada kodlamanın amacı başlığında olduğu gibi, bir başlıkta bulunan toplam yanıt sayısı toplam katılımcı sayısı olan 22'den fazla olabilir. Bunun sebebi katılımcıların yanıtlarının birden fazla kategori veya alt kategori altında gruplanması ve konuyla ilgili olmayan diğer kategorisi altında toplanan cevapların varlığıdır.

\section{Kodlama için temel kavram ve beceriler}

Veri analizi sonucunda kodlama eğitimi ile öğrencilere öğretilmesi gereken temel kavram ve beceriler ile ilgili olarak sekiz kategori ortaya çıkmıştır. Bu kategoriler problem çözme, analitik düşünme, farklı düşünme, üretken olma, algoritmik düşünme, programlamanın temel kavramları, sistematik düşünme ve diğer olarak isimlendirilmiştir. Bu kategoriler Tablo 3'de özetlenmiştir.

Tablo 3.

Kodlama için temel kavram ve becerilere ait kategoriler (katılımcı sayısı)

\begin{tabular}{ll}
\hline Ana Başlık & Kategori \\
\hline Kodlama İçin Temel Kavram ve & Problem çözme (9) \\
Beceriler & Analitik düşünme (7) \\
\hline
\end{tabular}




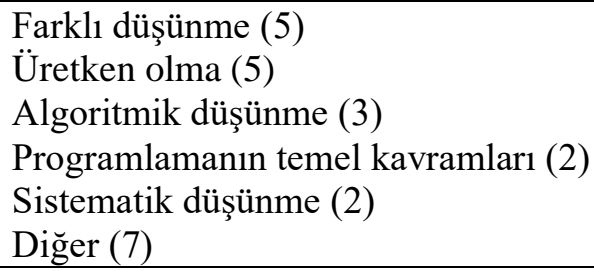

Ortaya çıkan kategoriler alanyazında tanım ve çerçeveleri temel olarak çizilmiş kavram ve becerilerdir. Katılımcılar bu kavram ve becerilerden bahsetmelerine rağmen söyledikleri şeyler kimi zaman alanyazından bağımsız ve muğlak olarak nitelendirilebilir. Bu duruma aşağıdaki alıntı örnek olarak verilebilir.

"Kavram ve beceriler hakkında tam bir bilgim yok açıçası o konuda... Yani... Kavram ve beceriler... Yani çocuğun mantıksal düşünmesini, sorunlarını çözme becerileri ııı... daha sonra ve ileriyi görme yani ilerde bir harita oluşturabilmesi yani ilerde yaşayabileceği, ileri görüşlülügü̈ne artı olabilir... Farklı düşünme becerileri gelişstiriyorlar... Başka şu an aklima gelenler bunlar." Ö16

Problem çözme kategorisi altında dokuz katılımcı bulunmaktadır. Bu dokuz katılımcıdan dördü genel olarak problem çözme becerisinden bahsederken diğer beş katılımcı öğrencilere problemleri farklı yollardan çözebilme, çözüm odaklı olma, problemleri kısa yoldan çözebilme gibi becerilen kazandırılması gerekliliğinden bahsetmiştir. Aşağıdaki örnek alıntıda katılımcı problem çözme ile ilgili olarak alternatif çözümler ve pratik düşünme gibi kavramlardan bahsetmektedir.

"Hazırlamış olduğum yıllık programı açarsak benim kodlamaya dair ilk kazanımlarım problem kavramını tanımlar. Problem çözmeye odaklanır. Bir problem için farklı çözüm alternatifleri sunar. Aslında kodlama diyoruz ya hayatımızın içinde. Tamam kodlama bir dilden bahsediyor olabiliriz ama hayatı da ilişkilendirebiliriz. Çocuklara pratik düşünmeyi, sorunlara farklı çözüm yolları üretmeyi de ögretebilir bu ders aynı zamanda. ”ö9

Analitik düşünme kategorisi altında yedi katılımcı bulunmaktadır. Katılımcıların analitik düşünmeden ne kast ettiği tam olarak anlaşılamamıştır. Görüşmeler yarı yapılandırılmış görüşme formu kullanılarak yapıldığ 1 için görüşmeci katılımcılara anlatmak istediği şeyleri detaylandırması ve açık bir şekilde sunması için firsatlar yaratmaya çalışmıştır. Fakat katılımcılar analitik düşünmede olduğu gibi bazı durumlarda anlatmak istedikleri şeylerden kısaca bahsetmiş ve detay vermemiştir. Aşağıdaki alıntı bu duruma örnek olarak verilebilir.

"Yani bir analitik düşünme becerisi geliştirebilir. Çünkü ders siz de bilirsiniz ayrıntıll olduğu için kodlama işi düzen gerektirdiği için, çocuklara bu düzen ve analitik düşünme becerisini kazandirabilir." Ö11

Katılımcılardan beşi kodlama eğitimi ile kazandırılması gereken beceri olarak farklı düşünme becerisini ileri sürmüştür. Bu katılımcılardan iki tanesi sadece öğrencilerin farklı açılardan düşünmesini vurgulamıştır. Geriye kalan beş katılımcının tamamı ise farklı düşünmeyi yaratıcı düşünme bağlamında ortaya koymuştur. Öğrencilerin var olan veya onlara sunulan yollardan ziyade yaratıcılıklarını kullanarak farklı yollar oluşturması gerekliliğinden bahsetmişlerdir. Kodlama eğitimi ile öğrencilere kazandırılması gereken kavram ve beceriler başlığı altındaki bir diğer kategori ise üretken olmadır. Üretken olma kategorisi altında beş katılımcı bulunmaktadır. Bu katılımcılardan ikisi öğrencilerde üretme duygusunun geliştirilmesi gerektiğginden bahsetmiştir. Son üç katılımcı ise öğrencilerin yaratıcılıklarını kullanarak üretim odaklı düşünmelerine yardımcı olmaktan ve onlara üretici bireyler olabileceğini göstermekten bahsetmektedir. 
Kodlama eğitimi ile öğrencilere kazandırılması gereken kavram ve beceriler başlığı altındaki bir diğer kategori algoritmik düşünmedir. Algoritmik düşünme kategorisi altında üç katılımc1 bulunmaktadır. Algoritmik düşünme kodlama eğitimi kapsamındaki en önemli becerilerden birisidir. Kodlama eğitimi bağlamında katılımcıların büyük bir çoğunluğunun algoritmik düşünmeden bahsetmesi beklenilmelidir. Katılımcıların büyük bir çoğunluğu algoritmik düşünmeyi vurgulamadığı gibi algoritmik düşünmeden bahseden üç katılımcıdan ikisi algoritmik düşünme becerisinden açık bir şekilde bahsetmemiştir. Bunlardan yalnızca bir tanesi problemler karşısında öğrencilerin yapacaklarını ve izleyeceği yolu oluşturabilmesinden bahsetmiştir. Aşağıdaki alıntı bu kategori için örnek olarak verilebilir.

"Şöyle bir şey mesela bilgisayar başında ihtiyaç duyduğu bir program konusunda kendi algoritmasını yazabilmesi kendi kafasında veya kullandı̆̆ programda, örneğin bir oyun oynuyor, oyunda topa mesela tekme atıyor topa tekme attı̆̆ında karşılaşabileceği durumlarla ilgili algoritmay düşünebilmesi, kafasinda oluşturabilmesi, şemalaştırabilmesi yani ben bunun kodunu yazsaydım şu şekilde yazardım diyebilmesi..." $\ddot{O} 5$

Kodlama eğitimi ile öğrencilere kazandırılması gereken kavram ve beceriler başlığ altındaki sıradaki iki kategori programlamanın temel kavramları ve sistematik düşünmedir. Her iki kategoride de iki katılıme bulunmaktadır. Programlamanın temel kavramları kategorisindeki katılımcılar öğrencilere koşullar ve döngüler gibi programlamanın temel bilgilerinin verilmesi gerektiğinden bahsetmiştir. Sistematik düşünme kategorisinde bulunan katılımcılar ise sistematik düşünmeyi net bir şekilde tanımlamadan kısa bir şekilde öğrencilerin sistematik düşünmeyi öğrenmesi gerektiğinden bahsetmişlerdir. Son olarak diğer kategorisinde konu ile ilgili olmayan veya az frekanslı yedi yanıt bulunmaktadır.

\section{Kodlama eğitimi için gerekli donanım ve yazılımlar}

Bu başlık altında katılımcıların kodlama eğitimindeki kavram ve becerilerin öğretilebilmesi için kullanılması gereken donanım ve yazılımlar ile ilgili düşünceleri üzerinde durulmuştur. Katılımcıların bu başlık altında blok tabanlı programlama araçlarından (22 katılımcı), robotik kitlerden ( 9 katılımc1), üç boyutlu tasarım yazılımlarından ( 5 katılımc1), metin tabanlı ortamlardan (3 katılımc1), mobil kodlama ortamlarından ( 2 katılımc1) ve bilgisayarsız bilgisayar bilimi etkinliklerinden (1 katılımc1) bahsettikleri görülmüştür. Bu kategoriler ile ilgili bilgiler Tablo 4'de özetlenmiştir. Katılımcıların bahsettiği araçların çeşitliliği açısından ciddi bir dengesizlik bulunmaktadır. Katılımcılar büyük bir oranda blok tabanlı ortamlar ve robotik kitlerden bahsetmelerine rağmen bilgisayarsız bilgisayar bilimi etkinliklerinden yalnızca bir katılımcı bahsetmiştir.

Tablo 4.

Kodlama için gerekli donanım ve yazılımlara ait kategoriler (katılımcı sayıs1)

\begin{tabular}{lll}
\hline Ana Başlık & Kategori & Örnekler \\
\hline Kodlama Eğitimi için & Blok tabanlı programlama & Scratch \\
Gerekli Donanım ve & araçları (22) & Code.org \\
Yazılımlar & & Hacker.can \\
& & Alice \\
\cline { 2 - 3 } & Robotik (9) & Blockly Game Ozoblockly.com \\
\hline & & Arduino \\
& & Maestro Education Makeblock \\
& Üç boyutlu tasarım yazılımları & Dash \& Dot \\
& $(5)$ & Tinkercad \\
& & Sketchup \\
& & \\
\hline
\end{tabular}




\begin{tabular}{ll} 
Metin tabanlı ortamlar (3) & Visual Basic \\
& PHP \\
& ASP \\
\hline Mobil kodlama ortamları (2) & Android Studio \\
$\begin{array}{l}\text { Bilgisayarsız bilgisayar bilimi } \\
\text { (1) }\end{array}$ & Lego \\
\hline
\end{tabular}

22 katılımc blok tabanlı kodlama ortamlarından bahsederken Scratch'i, 15 katılımc1 Code.org'u, 5 katılımcı Hacker.can'ı örnek vermiştir. Alice, Blockly Game, Ozoblockly.com vb. blok tabanlı programlama araçlarından dört katılımcı bahsetmişlerdir. Dokuz katılımcı blok tabanlı programlama ortamlarını kullanmasının nedenini bu ortamların eğlenceli ve ilgi çekici olmasını sebep olarak göstermiştir. Beş katılımeı ise blok tabanlı kodlama ortamlarının öğrencilerin seviyesine uygun olduğu için kullanılması gerektiğini öne sürmüştür. Buna ek olarak beș katılımcı popüler olduğu için blok tabanlı kodlama ortamlarının kullanılması gerektiğini savunmuştur. Bir diğer beş katılımcı ise blok tabanlı kodlama ortamlarının öğrenciler tarafından kolaylıkla öğrenildiği için kullanılması gerektiğini savunmuştur. Farklı bir bakış açısına sahip olan üç katılımcı ise blok tabanlı kodlama ortamlarının öğretmenin kodlamayı öğretmesini kolaylaştırdığı için bu ortamları tercih ettiğinden bahsetmiş̧ir. Son olarak üç katılımcı ücretsiz olması, erişim kolaylığ1 sağlaması, küçük boyutlu olmas1 ve Türkçe dil desteği bulunması gibi yazılım ile ilgili özelliklerden dolayı blok tabanlı kodlama ortamlarını tercih ettiklerini dile getirmişlerdir.

Dokuz katılımcı kodlama eğitiminde robotik kitlerin kullanılması gerekliliğinden bahsetmiştir. Katılımcıların üçü Arduino'dan ve birer katılımc1 da Maestro Education, Makeblock, Dash \& Dot robot gibi uygulamalardan bahsetmiştir. Katılımcılar robotik kitlerini kullanma sebebi olarak robotik etkinliklerde yazılan programın sonucunun somut olarak görülebilmesi, meslektaş tavsiyesi, öğrencilerin seviyesine uygun olması ve öğrencilere üretme duygusunu verebilmesini göstermişlerdir. Bazı katılımcılar ise sadece robotik yazılım diyerek uygulama ismi vermemiştir. Katılımcılar bu yazılımları kullanma nedeni olarak ise; öğrencilerin geliştirdikleri yazılımlar ile robotu hareket ettirme ve bunu nasıl gerçekleştirdiklerini öğrenmelerinin ve yapılan programlamanın sonucunu somut olarak görme imkânının ilgilerini çekmesi, meslektaş tavsiyesi, öğrenciler tarafından kolayca öğrenilebilmesi ve bir şeyler üretebileceklerinin farkına varmalarını sağlamasından bahsetmişlerdir. Aşağıdaki alıntıda Ö7 Ardunio'nun Scratch ile birlikte kullanılabildiğinden ve öğrenciler tarafindan kolayca öğrenildiğinden bahsetmiştir. Buna ek olarak yazılan programların sonucunun doğrudan gözlenebileceğini belirtmiştir.

"Yaş aralı̆̆ı bence iyi hani çocukların çok çabuk anlayabileceği bir şey bu Ardunio. Ardunio da en azından o basit Scratch 'la Ardunio 'yu kullanabiliyorsun o yönden seçerdim ya hani eee yaptığım programlamanın da sonucunu direkt o Ardunio sayesinde görebiliyorsunuz." Ö7

Beş katılımcı kodlama eğitimi ile öğrencilere kazandırılması gereken kavram ve beceriler için üç boyutlu tasarım yazılımlarının kullanılabileceğinden bahsetmiştir. Katılımcılardan üçü Tinkercad, ikisi Sketchup ve birisi Coreldraw'ı üç boyutlu tasarım yazılımlarına örnek olarak vermişlerdir. Bu katılımcılar üç boyutlu tasarım yazılımlarını tercih nedeni olarak öğrencilerin anlayabileceği şekilde tasarlanmış olmalarını, eğlenceli olmalarını, görsel olarak zenginleştirilmiş olmalarını, oyun tabanlı bir ortamda öğrencilere kendi tasarımlarını oluşturma imkânı sunmalarını, erişim kolaylığı sağlamalarını, ücretsiz ve küçük boyutlu olmalarını göstermiştir. Katılımcıların blok tabanlı ortamlar ve robotik kitler açısından verdiği yanıtlar ile üç boyutlu tasarım yazılımları açısından verdiği yanıtlar arasında fark bulunmaktadır. Katılımcılar blok tabanlı ortamlardan ve robotik kitlerden bahsederken bu ortamların programlama öğretimini kolaylaştırması ve yazılan programların sonuçlarının somut olarak görülebilmesi gibi pedagojik 
özelliklerinden bahsetmişlerdir. Fakat kodlama eğitimi için üç boyutlu tasarım yazılımlarının kullanılması gerektiğini söyleyen katılımcılar bu tasarım yazılımlarının kodlama eğitiminde tam olarak hangi pedagojik amaca hizmet edeceğinden bahsetmemişlerdir.

Kodlama eğitiminde metin tabanlı ortamların kullanılmasını belirten üç katılımcı bu ortamlara örnek olarak Visual Basic, PHP, Asp gibi metin tabanlı programlama dillerinden bahsetmiştir. Katılımcılar bu ortamlardan bahseden öğretmenler herhangi bir gerekçe sunmamışlardır. Katılımcılardan ikisi ise, kodlama eğitiminde mobil kodlama ortamlarının kullanılabileceğinden bahsetmiştir. Android Studio bu ortamlara örnek olarak verilmiştir. Bu katılımcılar kodlama eğitiminde mobil kodlama ortamlarının kullanımına gerekçe olarak öğrenciler arasında telefon ve tabletlerin yaygın olarak kullanıldığını ve telefon ve tabletlerin onların ilgi alanına yönelik olacağını göstermişlerdir. Son olarak bilgisayarsız bilgisayar bilimi başlığında bir katılımcı, kodlama eğitimi ile öğrencilere kazandırılması gereken kavram ve beceriler için Legoların kullanılabileceğinden bahsetmiştir. Aşağıdaki alıntıda Ö21 okullar arası olabilecek donanımsal eşitsizliğin giderilmesi açısından bakarak bilgisayarsız bilgisayar bilimi etkinliğinden bahsetmektedir. Fakat verilen yanıtta alanyazında yaygın olarak belirtilen bilgisayarsız bilgisayar bilimi etkinliklerinden ve bu etkinliklerin pedagojik özelliklerinden bahsedilmemiştir.

"Illkokul ortaokulda yani şuan Avrupa'da neler kullanillyor tam bilmiyorum da bizim ülkemizde bununla ilgili yazılmış birkaç kitap var ama daha çok kolejdeki öğrencilerin alabileceği kaynaklar falan olduğu için ben şimdi açık söyleyeyim ben tamamı tüm eşitlik olarak baktı̆̆ım için tüm ülkeye şöyle söyleyeyim tamamen minimum malzemeyle eğiticilerin tamamen sorular şeklinde analitik düşünmeye algoritmik düşünmeye yönlendirebileceği bir yapılar olsun isterim ben. Mesela en basit en ucuzu nelerdir, Legolar." Ö21

\section{Bilgisayarsız bilgisayar bilimi}

Katılımcıların tamamı kodlama eğitiminde kullanmak üzere robotik veya bilgisayar tabanlı farklı teknolojik ortamlardan bahsetmişlerdir. Katılımcılara bu teknolojik ortamları kullanılmadan kodlama eğitimi için gerekli olan bilgi ve becerilerin öğretilmesi hakkında ne düşündükleri sorulmuştur. Sonuç olarak üç kategori ortaya çıkmıştır. Bu kategoriler bilgisayarsız bilgisayar biliminden bahsetmeyenler, enformel bilgisayarsız bilgisayar bilimi ve bilgisayarsız bilgisayar biliminden bahsedenlerdir. Bu kategoriler ile ilgili bilgiler Tablo 5 'te özetlenmiştir.

Tablo 5 .

Bilgisayarsız bilgisayar bilimine ait kategoriler (katılımc1 sayıs1)

\begin{tabular}{ll}
\hline Ana Başlık & Kategori \\
\hline Bilgisayarsız Bilgisayar Bilimi & Bilgisayarsız bilgisayar biliminden bahsetmeyenler (15) \\
& Enformel bilgisayarsız bilgisayar bilimi (4) \\
& Bilgisayarsız bilgisayar biliminden bahsedenler (3) \\
\hline
\end{tabular}

Bilgisayarsız bilgisayar biliminden bahsetmeyen kategorisi altında on beş katılımcı bulunmaktadır. Bu katılımcılar yukarıda bahsi geçen soruya yanıt verirken alanyazında net bir şekilde tarif edilen bilgisayarsız bilgisayar bilimine atıfta bulunmamışlardır. Bu katılımcılar bundan da öte yazılım ve elektronik donanımlar olmadan kodlama eğitiminin verilemeyeceğini iddia etmiştir. On beş katılımcıdan dokuzu anlatılan konuların soyut kalacağını ve öğrenilen bilgilerin kalıcı olmayacağını gerekçe göstererek yazılım ve elektronik donanımlar olmadan kodlama eğitiminin verilemeyeceğini belirtmişlerdir. Bilgisayarsız bilgisayar biliminden bahsetmeyen katılımcılardan üçü ise bilgisayarsız bir ortamda kodlama eğitiminin nasıl yapılacağı hakkında bilgi sahibi olmadıklarını belirtmiştir. Son olarak üç katılımcı ise bilgisayar kullanılmadan yapılacak etkinliklerin veya öğretimin algoritma ve akış diyagramları öğretiminden ileri gidemeyeceğinden bahsetmiştir. Aşağıdaki alıntıda katılımcı bilgisayarsız 
bilgisayar bilimi hakkında bilgisi olmadığını belirtmiştir ve bilgisayarsız olarak yapılacak etkinliklerin verimsiz olacağını iddia etmiştir.

"Şu an benim yaptığım şey o aslında kodlama, bu yazılım ve donanımları kullanmadan dediği gibi aklş diyagramlart ve algoritmalardan öteye geçilebileceğini düşünmüyorum hani çünkü bu sonuçta bu biraz daha uygulayarak, yaşayarak öğrenilebilecek konular. Ben en azından bulunduğumuz imkânlarda işte çocuklar bir üst eğitim öğretim kurumuna geçtiğinde en azından işin bir noktasının farkına varmış biliyor olmaları da benim için bir kar diye düşünüyorum. Yani ben düşündüm hani nasıl yapılabilir o imkânlar olmadan ben ona bir cevap bulamadım açıkçası. Hadi ben tahtada gösteririm. Tahtaya bir kodlama programı kurup ben ögrencilerime gösteririm ama sizce bu ne kadar kalıcı olur? ” Ö9

Enformel bilgisayarsız bilgisayar bilimi kategorisi altında 4 katılımcı bulunmaktadır. $\mathrm{Bu}$ katılımcılar bilgisayarsız bilgisayar bilimi kavramından formel olmayan öğrenme ortamları aracılığı ile haberdar olduklarını belirtmişlerdir. Bu katılımcılar kodlama eğitimindeki kavram ve becerilerin öğretiminin yazılım ve elektronik donanımları kullanmadan oyunlarla yapılabileceğine ilişkin, öğrencilere yönerge hazırlayıp saklı olan bir şeyin buldurulması, kare boyama, algoritma ile ilgili yön buldurma gibi örnekler vermişlerdir. Son olarak bu dört katılımc1 bu tip etkinliklere tam olarak hâkim olmadıklarını da belirtmiştir.

Bu başlık altında bulunan son kategori olan bilgisayarsız bilgisayar biliminden bahsedenler kategorisi altında üç katılımcı bulunmaktadır. Bu katılımcılar katıldıkları eğitimler, atölye çalışmaları gibi faaliyetler sonucunda bilgisayarsız bilgisayar bilimi etkinliklerinden haberdar olduklarını ifade etmişlerdir. Bilgisayarsız bilgisayar bilimi etkinlikleri olarak, oyun kartları hazırlama, kâğıt üzerinde çeşitli zekâ oyunları, define avı benzeri oyunlar, code.org benzeri bilgisayarsız yapılabilecek uygulamalar gibi etkinliklerin yapılabileceğinden haberdar olduklarını söylemişlerdir. Fakat bu üç katılımcının üçü de bilgisayarsız bilgisayar bilimi etkinliklerinin faydalı olacağını düşünmediklerini belirtmiştir. Bu katılımcılara göre kodlama öğrenirken öğrencilerin yazılım ve donanımlarla etkileşimde olmaları gerekmektedir, öğrenciler bilgisayarsız etkinlikleri uygularken sıkılabilirler ve bu etkinliklerin uygulanması zor olabilir.

\section{Öğretmen eksiklikleri}

Katılımcılara bilişim teknolojileri ve yazılım dersi öğretmenlerinin kodlama eğitimi açısından eksik olduğu noktalar sorulmuştur. Katılımcılardan gelen yanıtlar sonucunda temel olarak öğrenciler için kodlama ortamları (teknoloji bilgisi), pedagoji bilgisi ve alan bilgisi olmak üzere üç kategori ortaya çıkmıştır. Bu kategoriler ile ilgili bilgilere Tablo 6'dan ulaşılabilir.

Tablo 6.

Öğretmen Eksikliklerine Ait Kategoriler (Katılımcı Sayısı)

\begin{tabular}{ll}
\hline Ana Başlık & Kategori \\
\hline Öğretmen Eksiklikleri & Öğrenciler için kodlama ortamları (7) \\
& Pedagoji bilgisi (7) \\
& Alan bilgisi (6) \\
\hline
\end{tabular}

Öğrenciler için kodlama ortamları kategorisinde yedi katılımcı bulunmaktadır. Kodlama ortamları teknolojik pedagojik alan bilgisindeki teknoloji bilgisine denk gelmektedir. Bu katılımcılar lisans döneminde öğrenilen kodlama teknolojileri ile ortaokul öğrencilerine öğretilen kodlama teknolojilerinin farklı olduğunu söylemiştir. Katılımcılar meslekte ilerlemiş öğretmenlerin güncel platformları bilmiyor olabileceğinden ve öğretmenlerin teknolojideki değişim hızına yetişme konusunda yetersiz kalabildiğinden bahsetmişlerdir. Aşağıdaki alıntı bu kategoriye örnek olarak verilebilir. 
"Şöyle deyim $\imath$ benim mezun olduğum okulda bana ögretilen programlar şunlar; Delphi, Pascal, PHP ama gelgelelim buraya geldiğinde Delphi'yi Pascal'ı veya PHP'yi anlatamazsın ki bizim hocalarımızın hepsi mühendislik bölümü mezunu olduğu için bizden hep mühendislikle ilgili şeyler istediler. Siteden mesela bi mağaza programı istediler ama ben o mağaza programı burada işime yaramaz o yüzden eksiklerimiz biraz oradan kaynaklanıyor... Elimizden geldiğince kendimizi geliştirmeye çalışıyoruz Skecthup'tır Scratch 'tır. Genellikle birazcık daha üniversitedeki gibi değil de ortaokuldaki ögrencilerin seviyesine inmeye çalışmakta biraz sıkıntılarımız var. "Ö3

Katılımcılar öğretmenlerin teknoloji bilgisi dışında pedagoji bilgisi anlamında da eksikliklerinin olabileceğini belirtmişlerdir. Bu başlığın ikinci kategorisi olan pedagoji bilgisinde de yedi katılımcı bulunmaktadır. Pedagoji bilgisi alanındaki eksikliklerden bahseden katılımcılar lisans döneminde aldıkları dersler içerisinde kodlamanın öğretimine özgün derslerin bulunmadığını ve bu nedenle ortaokul düzeyindeki öğrencilere kodlama eğitimi verme noktasında sıkıntı yaşadıklarını dile getirmişlerdir. Aşağıdaki alıntıda katılımcı kodlama açısından pedagoji bilgisinin yeterli düzeyde olmadığını ve lisans döneminde aldığı derslerin kodlama eğitimi açısından eksik kaldığını ifade etmiştir.

"Ben kendimi örnek veriyim. Ben bu konuda eksik hissediyorum kendimi, yani müthiş eksiğim hatta şöyle söyleyeyim kodlama eğitimi verebilecek bilgi düzeyim \%10'dur belki öyle söyleyeyim size. Niye diyeceksiniz çünkü kodlama bilmek ayrl şey ögrretmek ayrı şey bunu nasıl aktaracağınız konusunda benim üniversite yllarımda aldığım ĕgitimi yeterli görmüyorum açıkçası. Şimdi belki yeni bilgisayar öğretmenleri bilişim BÖTE bölümlerine koyuyorlar bu dersi ama onlarınki de yeterli değil onlar da çok geriden takip ediyorlar. İşte şimdi biz tam böyle ateşin olduğu noktadayız şu an. Öğrencilerin beklentileri ile yetişen ögretmenlerin hazır bulunuşlukları aynı düzeyde değil ..." Ö5

$\mathrm{Bu}$ başlık altındaki üçüncü ve son kategori alan bilgisidir. Bu kategoride altı katılımcı bulunmaktadır. Bu katılımcılar genel olarak öğretmenlerin kodlama konusunda bilgi ve beceri eksikliklerinin olduğunu düşünmektedir. Öğretmenlerin lisans mezuniyetinden sonra belirli bir süre geçmiştir. Öğretmenler bu geçen sürede bilgilerini tazeleme imkânı olmadığ 1 için öğrendiği kodlama bilgisini unutmuş olabilirler. Bunun dışında öğretmenler lisans düzeyinde kendilerini kodlama konusunda yeteri kadar geliştirmemiş olabilirler. Bu yüzden öğretmenlerin kodlama bilgisi yönünden birçok eksikliği bulunabilir. Aşağıdaki alıntı bu kategoriye örnek olarak verilebilir.

"Tabi yani özelliklede ilk yllları olmayanlar benim gibi 5 yllın üstü olanlar körelmiştir biraz. Çünkü eğer ekstra bir iş yapmadiysa Word, Excel, PowerPoint anlattyoruz paso. Düşünsene şimdi 10 ylllı bilgisayar öğretmeni Word, Excel PowerPoint anlattyor. Körelmiştir kesinlikle, biraz açacak bakacak biz u şimdi şöyle söyleyeyim mezun olduğum bir arkadaşla kendi çapımızda program falan da yazmaya çalışıyoruz bir şeyler yapmaya çalışlyoruz." Ö1

\section{Tartışma, Sonuç ve Öneriler}

$\mathrm{Bu}$ çalışmanın amacı bilişim teknolojileri ve yazılım dersi öğretmenlerinin kodlama eğitimine yönelik düşünce ve görüşlerini ortaya çıkarmaktır. Bilişim teknolojileri ve yazılım dersi öğretmenleri ile görüşmeler yapılıp nitel veri toplanmıştır. Öğretmen görüşleri (i) kodlamanın amac1, (ii) kodlama için temel kavram ve beceriler, (iii) kodlama eğitimi için gerekli donanım ve yazılımlar, (iv) bilgisayarsız bilgisayar bilimi ve (v) öğretmen eksiklikleri isimli başlıklar altında incelenmiştir.

Öğretmenlerin görüşleri kodlamanın amacı açısından incelendiğinde onların ağırlıklı olarak ekonomik ve bilişsel açıdan kodlama eğitimini değerlendikleri ortaya çıkmıştır. Yirmi iki öğretmenden yirmisi kodlama eğitiminin amacını ekonomik açıklayan irdeleyen cevaplar 
vermiştir. Öğretmenlerin ekonomik açıdan yaptığı değerlendirmeler alanyazına paralel bir şekilde çağımızın gerekliliği olarak üretici bir toplum olabilmek için bilgisayar bilimine hâkim bireyler yetiştirmek, teknolojik üretim ile ülke kalkınmasına katkı sağlamak, yazılımın sağladığı iş olanaklarından faydalanmak ve küçük yaşlarda üretici bireyler yetiştirerek teknoloji üreten bir toplum haline gelmek ve ülke ekonomisine katkı sağlamak gibi sebeplere dayanmaktadır. $\mathrm{Bu}$ gerekçeler incelendiğinde öğretmenlerin alanyazındaki kodlama eğitiminin sağlayacağ ekonomik olanaklardan haberdar olduğu söylenebilir (Aytekin, Çakır, Yücel ve Kulaözü, 2018). Bu çalışmanın bulgularına paralel olarak Gültepe (2018) bilişim teknolojileri ve yazılım dersi öğretmenlerinin kodlama eğitiminin ekonomik açıdan sağladığı olanakları vurguladıklarını bulmuştur. Benzer şekilde Yecan, Özçınar ve Tanyeri (2017) öğretmenlerin kodlama eğitimi sayesinde öğrencilerin teknoloji kullanımında tüketici olmaktan üreticiliğe geçişte etkisinin olacağını iddia etmektedir.

Ekonomi çerçeveli görüşlerinin aksine öğretmenlerin bilişsel açıdan ortaya koyduğu görüşler sayı olarak daha azdır ve daha sınırlıdır. Öğretmenlerden sadece altısı problem çözme ile ilgili düşüncelerini dile getirmişlerdir. Bu öğretmenlerden dördü aynı zamanda algoritmik düşünmeden bahsetmiştir. Bunun yanında analitik düşünmeden bahseden dört ve yaratıcılıktan bahseden üç öğretmen bulunmaktadır. Yecan, Özçınar ve Tanyeri (2017) öğretmenlerin öğrencilerin problem çözme, mantıksal düşünme, algoritmik düşünme ve yaratıcılık becerilerinin geliştirilmesi için kullanılabileceğini düşündüğünü belirtmiştir. Benzer şekilde Ceylan ve Gündoğdu (2018) bilişim teknolojileri ve yazılım dersi öğretmelerinin öğrencilerin problem çözme, akıl yürütme, eleştirel düşünme, analitik ve algoritmik düşünme becerilerini geliştirmeye olumlu katkı sağlayacağını ifade ettiklerini ortaya koymuştur. Bilgi işlemsel düşünme literatüründe kodlama eğitimi ile öğrencilere temel olarak soyutlama, algoritmik düşünme, problem çözme, problemleri bileşenlerine ayırma, algoritmanın değerlendirilmesi ve algoritmanın genelleştirilmesi gibi temel becerilerin öğretilmesi gerektiği vurgulanmaktadır (Çetin ve Toluk Uçar, 2017). Alanyazındaki temel başlıklar açısından değerlendirildiğinde öğretmenlerin soyutlama, problemleri bileşenlerine ayırma, algoritmanın değerlendirilmesi ve algoritmanın genelleştirilmesi becerilerinden açık bir şekilde bahsetmedikleri görülmektedir. Görüşmeler esnasında görüşmeci öğretmenlere kodlamanın amacına yönelik görüşlerini sunması için gerekli zamanı ve firsatları yaratmıştır. Bu halde öğretmenlerin alanyazındaki temel kavramlardan bahsetmemesi öğretmenlerin bu konuda yeterli olmayabileceği görüşünü desteklemektedir.

Öğretmenlerin görece olarak daha az sayıda bilişsel becerilerden bahsetmesi ve alanyazında bahsi geçen temel becerilerin bazılarından bahsetmemesinin yanında onların belirli becerilerden bahsederken detaya girmediği ve kısa cümleler kullandığı gözlenmiştir. Bu durum analitik düşünme ve yaratıcılık kategorilerinde açık bir şekilde ortaya çıkmaktadır. Öğretmenler sadece "çocukların analitik düşünmesini geliştirmek amacı ile" ve "Yani yaratıcılıklarını geliştireceğini düşünüyorum ben." gibi kısa cümleler kurarak bu becerilerden bahsetmiş̧ir. Fakat alanyazında bahsi geçen her bir beceri kendi başına geniş bir alanyazına sahiptir. Öğretmenlerin bu becerilerden, firsatları ve zamanları olduğu halde, kısaca bahsetmesi onların bu konuda eksik olabileceği görüşünü destekler niteliktedir.

Öğretmenlerin bilişsel açıdan ortaya koyduğu görüşlerin sayı olarak daha az ve daha sınırlı olmasına ek olarak onların bazı görüşlerinin de alanyazın ile uyumlu olmadığı gözlenmiştir. Öğretmenlerin görüşleri incelendiğinde öğrencilerin kodlama eğitiminde kazandığ becerileri günlük yaşam problemlerinin çözümünde kullanabileceklerinden bahsettikleri görülmüştür. Bilgi işlemsel düşünme alanyazını tam olarak öğretmenlerin bu iddialarını desteklememektedir (Guzdial, 2015). Belirli bir alanda öğrenilen bilgiyi başka bir alanda kullanmak yani onu farklı alanlara transfer etmek zor bir süreçtir (Perkins ve Salomon, 2012). Kodlama eğitimi bağlamında ele alınan konu, kavram veya becerilerin başka alanlara aktarımı otomatik olarak gerçekleşmez ve ciddi bir çabayı gerektirir (Salomon ve Perkins, 1987).

Bilişim teknolojileri ve yazılım dersi öğretmenlerine kodlama için temel kavram ve beceriler hakkında görüşleri de sorulmuştur. Kodlama eğitiminde olması gerekli temel kavram ve beceriler başlığı altında kodlama eğitiminin amacı başlığına benzer bir durumun olduğu gözlemlenmiştir. Bu başlık altında şu kategoriler ortaya çıkmıştır: problem çözme, analitik 
düşünme, farklı düşünme, üretken olma, algoritmik düşünme, programlamanın temel kavramları ve sistematik düşünme. Alanyazın incelendiğinde öğretmenlerin bahsettiği bu kavram ve becerilere farklı ülkelerin müfredatlarında yer verdiği görülmektedir (Balanskat ve Engelhardt, 2015; National Curriculum, 2017; Tebliğler Dergisi, 2016). Ortaya çıkan her bir kategori tek başına alanyazında geniş bir yer tutmaktadır (Çetin ve Toluk Uçar, 2017). Fakat bilişim teknolojileri ve yazılım dersi öğretmenleri alan yazında geçen kavram ve becerilerin bazılarında bahsetmesine rağmen öğretmenlerin yaptıkları açılamalardaki temel kavramların tam olarak net olmadığ 1 ve kapsam ve içerik açısından görece olarak yüzeysel olduğu görülmektedir.

Öğretmenlere kodlama eğitimi için gerekli donanım ve yazılımlar ve bilgisayarsız bilgisayar bilimi hakkındaki görüşleri de sorulmuştur. Bu iki başlık ile ilgili sorular sorulmasının temel hedefi alanyazında bahsedilen farklı yaklaşımlar ile öğretmenlerin derslerinde kullandıkları araç tabanlı yaklaşımların karşılaştırılmasıdır. Alan yazında dört temel araç odaklı yaklaşım bulunmaktadır (Kert, 2018). Bunlar blok tabanl, robot tabanl, metin tabanlı kodlama ve bilgisayarsız bilgisayar bilimidir. Ayrıca bu yaklaşımlar birleştirilerek hibrit ortamlarda kodlama yaklaşımı da kullanılabilir. Öğretmenlerin verdiği cevaplar incelendiğinde öğretmenlerin tümünün blok tabanlı ortamlardan haberdar olduğu anlaşılmaktadır. Blok tabanlı ortamları kullanma nedeni olarak genel itibariyle oyun tabanlı öğrenme ortamı sunması, ilgi çekici ve eğlenceli olması, öğrenci düzeyine uygun olması ve karmaşık uygulamalar yapmaya imkân vermesi gösterilmiştir. Alanyazında bahsedilen blok tabanlı programlama araçlarının eğitimsel özellikleri incelendiğinde öğretmenlerin gerekçeleri ile literatürün paralel nitelikte olduğu görülmüştür (Çetin ve Toluk Uçar, 2017; Schwartz, Stagner ve Morrison, 2006).

Araştırmaya katılan yirmi iki öğretmenden dokuzu robot tabanlı ortamların kullanımından bahsetmiştir. Bu öğretmenler robot tabanlı ortamların kullanılmasının sebebi olarak yapılan programlamanın sonucunun somut olarak görülmesi ve öğrencilerin bir şeyler üretebileceklerini deneyimlemelerini göstermiştir. Alanyazın incelendiğinde robot tabanlı ortamların temel bilgi işlemsel düşünme becerilerinin geliştirilmesi için kullanılabileceği vurgulanmaktadır (Bers, 2008; Buss ve Gamboa, 2017; Üçgül, 2017). Bu ortamlarda öğrenciler soyut kavramları somut bir araç olan robot yardımıyla irdeleyebilirler. Bu ortamlarda tasarım süreçleri sonucunda bir ürün elde edebilirler. Alanyazında robot tabanlı ortamların eğitimsel özellikleri ile öğretmenlerin robot tabanlı ortamlar ile ilgili söyledikleri karşılaştırıldığında öğretmenlerin görece olarak sınırlı şeyler söylediği görülmektedir.

Öğretmenlerden yalnızca üçü metin tabanlı ortamların kullanılmasından bahsetmiştir. Öğretmenler Visual Basic, PHP, ASP gibi metin tabanlı programlama ortamlarının kodlama eğitiminde kullanılabileceğini söylemişlerdir. Fakat bu araçların pedagojik özelliklerinden bahsetmemişlerdir. Alanyazın incelendiğinde Logo, Small Basic ve Python gibi ortamların küçük yaştaki öğrenciler için kullanılabileceği söylenmektedir (Kandemir, 2017). Öğretmenlerin bu ortamların hiçbirinden bahsetmemesi ve metin tabanlı ortamların öğretimsel özelliklerine değinmemesi onların öğretimsel metin tabanlı ortamları bilgilerinin eksikliğine bir işaret olarak algılanabilir.

Kodlama eğitiminde kullanılan yaklaşımlardan biri de bilgisayarsız bilgisayar bilimi etkinlikleridir. Alanyazın incelendiğinde bilgisayarsız bilgisayar bilimi etkinliklerinin kodlama eğitiminde kavramsal süreçleri somutlaştırmada uygun bir seçenek olduğu ve teknolojik alt yap1 sorunu yaşayanlar için firsat eşitliği sunduğu söylenebilir (Kalelioğlu, 2017). Fakat araştırmaya katılan öğretmenlerden çok azı bilgisayarsız bilgisayar biliminden bahsetmiş̧tir. Bu öğretmenlerin bilgisayarsız bilgisayar bilimi öğretimi konusunda çoğunlukla fikir sahibi olmadıkları söylenebilir.

Genel olarak değerlendirmek gerekirse bu araştırmaya katılan öğretmenler blok tabanlı görsel programlama ortamlarından yaygın olarak bahsetmiştir. Bunu sırasıyla robotlar, 3B yazılımlar ve metin tabanlı ortamlar takip etmiştir. Görsel kodlama ortamlarının birinci sırada bulunması bu ortamlara erişimin kolay olması ve sağladığı kodlama olanakları göz önünde bulundurulduğunda doğal olarak algılanabilir. Fakat öğretmenlerin robotlar, metin tabanlı ortamlar veya bilgisayarsız bilgisayar biliminden çok sınırlı olarak bahsetmesi dikkate değer bir bulgudur. Ayrıca öğretmenlerin Logo, Small Basic ve Python gibi öğrenciler için uygun 
olabilecek metin tabanlı ortamlar yerine Visual Basic, PHP ve Asp gibi dillerden bahsetmesi onların eğitimsel olarak kullanılan metin tabanlı ortamlardan tam olarak haberdar olmadığına dair bir gösterge olarak alınabilir.

$\mathrm{Bu}$ araştırmadaki son başl1k öğretmenlerin kodlama eğitimine yönelik eksiklikleri ile ilgilidir. Öğretmenler teknoloji, pedagoji ve alan bilgisi yönünde eksikliklerinin olduklarından bahsetmiştir (Bell, Andreae ve Robins 2014; Brown, Sentance, Crick ve Humphreys, 2014; Menekse, 2015; Sands, Yadav ve Good, 2018). Öğretmenlerin bu eksikliklerine yönelik ortaya koyduğu sebepler irdelediğinde lisans eğitiminde kodlama eğitimine yönelik yeterli düzeyde pedagoji bilgisi verilmediği, üniversitede öğretilen teknolojiler ile okulda öğretilmesi gereken teknolojiler arasında farklılıklar olduğu, üniversitede yeterli düzeyde kodlama eğitimi verilmediği ve üniversitede öğrenilen alan bilgisinin öğretmen olduktan sonra unutulduğu ortaya konulmuştur.

Kodlama eğitiminde dünya çapında yaşanan hızlı bir değişim yaşanmaktadır ve bu değişimde öğretmenin rolü önemlidir (Sands, Yadav ve Good, 2018). Bu yüzden kodlama eğitiminde öğretmenlerin teknolojik, pedagojik ve alan bilgisi açısından durumu önemlidir. Bu çalışmada öğretmenlerin bahsi geçen boyutlarda bazı eksikliklerinin olduğu ortaya konulmuştur ve öğretmenlerin de eksikliklerinin farkında olduğu anlaşılmıştır. Öğretmenler kodlama eğitimini ağırlıklı olarak ülke ekonomisi açısından önemli bir araç olarak gördüklerini belirtmişlerdir. Ekonomik değerlendirmenin yanında öğretmenler kodlama eğitimini bilişsel açıdan çeşitli becerilerin gelişimi penceresinden de değerlendirmişlerdir. Fakat öğretmenlerin bilişsel açıdan ortaya koyduğu görüşler ekonomik açıdan ortaya koyduğu görüşlere göre daha sınırlı olduğu anlaşılmaktadır. Öğretmenlerdeki bu durum sadece onlara özgü olabileceği gibi daha genel de olabilir. Öğrenciler ve veliler de kodlama eğitimini ekonomik çerçeveden ele alıyor olabilirler. $\mathrm{Bu}$ durum öğrencilerin kodlama derslerine karşı tutumlarını etkileyebilir. İleride yapılacak çalışmalar yönetici, öğretmen, öğrenci ve velilerin kodlama eğitimine hangi açılardan baktığı ve bu bakış açılarının kodlama eğitimine nasıl yansıdığını araştırabilir.

Kodlama eğitiminin ekonomik ve bilişsel bileşenlerinin yanında sosyal boyutu da bulunmaktadır. Kafai ve Burke (2014) kodlama eğitiminin bireysel bir çaba olarak görülmesinin 21. yüzyılın gerçekleri ile uyuşmadığını söylemektedir. Onlara göre kodlama eğitimi sosyal ağlar ve kendin yap (do it yourself) kültürünün dijital üretim anlayışı ile birlikte kendini ifade etme biçimi ve sosyal topluluklara katılım olarak algılanmalıdır. Öğretmenler kodlama eğitiminin ekonomik ve bilişsel bakış açısına ek olarak kodlama eğitiminin sosyal boyutu ile de ilgilenmelidirler. Scratch benzeri kodlama ortamları aynı zamanda birer sosyal ağ olarak da kullanılmaktadır. Bireyler bu ortamlarda kendi programlarını paylaşıp diğerlerinin paylaştığı programları beğenme ve onlar hakkında yorum yapma gibi sosyal ağlarda bulunan özellikleri kullanmaktadırlar. Öğretmenlerin kodlamayı bu açıdan da değerlendirmesi verecekleri eğitimin içeriğini etkileyebilir.

Bu çalışmada ortaya konulduğu gibi öğretmenler kendilerini kodlama eğitiminin belirli bileşenleri açısından eksik hissetmektedir. Bu sadece Türkiye'ye özgü bir durum değildir. Yapılan uluslararası birçok araştırma öğretmenlerin kodlama eğitimi konusunda eksikliklerinin olduğunu göstermektedir (Menekse, 2015; Sands, Yadav ve Good, 2018). Bu eksiklerin giderilmesi için öğretmenlere hizmet içi eğitimler verilebilir. Bu sayede öğretmenlerin eksikliklerinin giderilmesine yardımcı olunabilir. Öğretmenlerin eksikliklerinin giderilmesinin yanında onların üniversitede aldığı eğitim ile güncel bilgiye sahip öğretmen yetiştirilmesi bir diğer hedef olarak görülmelidir. 2018 y1lından itibaren Bilgisayar ve Öğretim Teknolojileri Eğitimi bölümlerinde güncellenmiş bir öğretim programı uygulanmaktadır (YÖK, 2018). Öğretim programına yeni alan bilgisi ve kodlama pedagojisine yönelik dersler eklenmiştir. Alan derslerine örnek olarak fiziksel programlama ve mobil programlama verilebilir. Eğitim derslerine örnek olarak programlama öğretimi yaklaşımları ve bilişim öğretimi programları verilebilir. Bu çalışmanın amacı Bilgisayar ve Öğretim Teknolojileri Öğretmenliği lisans programına katkı yapmak veya genel bir değerlendirmede bulunmak değildir. Fakat bu çalışmada öğretmenlerin ortaya koyduğu gibi öğretmenler alan bilgisi konusunda kendilerini eksik hissetmektedir ve kodlama eğitimi literatüründe öğrenci kodlama başarısı ile matematik başarısı arasında ciddi bir 
ilişki bulunmaktadır (Cetin ve Dubinsky, 2017; Nasser-Abu Alhija ve Levi-Eliyahu, 2019). Matematik başarısı kodlama başarısı için önemlidir. Fakat Bilgisayar ve Öğretim Teknolojileri Eğitimi bölümü programındaki matematik dersleri azaltılmıştır. Bu durum donanımlı öğretmen yetiştirme amaciyla tezat halindedir.

Öğretmenlerin eksikliklerinin giderilmesi sadece pedagojik bir konu değildir. Aynı zamanda teknolojik alt yap1 gereksinimleri de önemlidir. Öğretmenlerin üniversite öğrenimleri süresince elektronik bileşenler, robotik donanımlar ve gerekli yazılımların bulunduğu kodlama eğitimi laboratuvarlarında zengin laboratuvar koşullarında öğrenim görmeleri onların alan bilgilerini geliştirmede yardımcı olabilir. Eğitim fakültelerinde kurulacak kodlama eğitimi laboratuvarları bu amaca hizmet edebilir.

Hizmet içi eğitimler ve lisans eğitiminin yanında öğretmen ve öğretmen adaylarının kendilerini geliştirmesi için bilişim teknolojileri ve yazılım dersi öğretmenleri meslek kuruluşlarına, akademisyenlere ve özel sektöre de görevler düşmektedir. Hali hazırda yapılan atölyeler ve eğitimlere yenileri eklenerek öğretmen ve öğretmen adaylarının gelişimine katkıda bulunulabilir. Son olarak bilişim ve öğretim teknolojileri hızlı bir şekilde ilerlemektedir. Lisans eğitiminde öğrenilen bilgiler hızlı bir şekilde güncelliğini yitirebilir. Fakat kodlama eğitiminin temel bileşenleri belirlidir. Bir kere öğrenildiğinde farklı ortam ve teknolojiler için kullanılabilir. Öğretmen ve öğretmen adayları aldıkları temel bilgileri yeni teknoloji ve gelişmeler ışığında kendi çabalarıyla güncelleyerek kendi gelişimlerini sağlayabilirler ve sağlamalıdırlar.

\section{Etik Kurul Onayı}

Çalışmanın etik ilkelere uygunluğu Bolu Abant İzzet Baysal Üniversitesi Sosyal Bilimlerde İnsan Araştırmaları Etik Kurulu'nun 2016/146 protokol numaral1, 14.11.2016 tarihli ve 2016/06 say1l1 toplantısında değerlendirilmiş ve uygunluğu 12050492-605-E.14453702 say1lı ve Araştırma izni (Aslı Göncü) konulu yazısıyla bildirilmiştir.

\section{Kaynaklar}

Aho, A. V. (2012). Computation and computational thinking. The Computer Journal, 55(7), 832835.

Aytekin, A., Çakır, F. S., Yücel, Y. B. ve Kulaözü, İ. (2018). Geleceğe yön veren kodlama bilimi ve kodlama öğrenmede kullanılabilecek bazı yöntemler. Avrasya Sosyal ve Ekonomi Araştırmaları Dergisi, 5(5), 24-41.

Balanskat, A. ve Engelhardt, K. (2015). Computing our future: Computer programming and coding-Priorities, school curricula and initiatives across Europe. European Schoolnet. Erişim adresi: http://fcl.eun.org/documents/10180/14689/ Computing+our+future_final. pdf/

Bell, T., Alexander, J., Freeman, I. ve Grimley, M. (2009). Computer science unplugged: School students doing real computing without computers. The New Zealand Journal of Applied Computing and Information Technology, 13(1), 20-29.

Bell, T., Andreae, P. ve Robins, A. (2014). A case study of the introduction of computer science in NZ schools. ACM Transactions on Computing Education, 14(2), 1-31.

Bers, M. U. (2008). Using robotic manipulatives to develop technological fluency in early childhood. N. Saracho ve B. Spodek (Yay. haz.), Contemporary Perspectives on Science Technology in Early Childhood Education içinde (ss. 105-225). Charlotte, NC: Information Age Publishing, In.

Brennan, K. ve Resnick, M. (2012). New frameworks for studying and assessing the development of computational thinking. Proceedings of the 2012 Annual Meeting of the American Educational Research Association, 1(25). Vancouver, Canada.

Brown, N., Sentance, S., Crick, T. ve Humphreys, S. (2014). Restart: The resurgence of computer science in UK schools. ACM Transactions on Computing Education, 14(2), 1-22.

Buss, A. ve Gamboa, R. (2017). Teacher transformations in developing computational thinking: Gaming and robotics use in after-school settings. P. J. Rich ve C. B. Hodges (Yay. haz.), 
Emerging Research, Practice, and Policy on Computational Thinking içinde (ss. 189203). Cham, Switzerland: Springer.

Ceylan, V. K. ve Gündoğdu, K. (2018). Bir olgubilim çalışması: Kodlama eğitiminde neler yaşaniyor? Eğitim Teknolojisi Kuram ve Uygulama, 8(2), 1-34.

Cetin, I. (2013). Visualization: A tool for enhancing students' concept images of basic objectoriented concepts. Computer Science Education, 23(1), 1-23.

Cetin, I. (2016). Preservice teachers' introduction to computing: exploring utilization of Scratch. Journal of Educational Computing Research. 54(7), 997-1021. DOI: $10.1177 / 0735633116642774$.

Cetin, I. ve Dubinsky, E. (2017). Reflective abstraction in computational thinking. The Journal of Mathematical Behavior, 47, 70-80.

Çetin, İ. (2016). Nitel içerik analizi. Y. Özden (Yay. haz.). Eğitimde Üretim Tabanli Çalişmalar Için Nitel Araştirma Yöntemleri, içinde (ss. 125-147). Ankara: Anı Yayıncılık.

Çetin, İ., ve Toluk Uçar, Z. (2017). Bilgi işlemsel düşünme tanımı ve kapsamı. Y. Gülbahar (Yay. haz.), Bilgi İşlemsel Düşünmeden Programlamaya, içinde (ss. 41-78). Ankara: Pegem Akademi.

Denner, J., Werner, L. ve Ortiz, E. (2012). Computer games created by middle school girls: Can they be used to measure understanding of computer science concepts? Computers \& Education, 58(1), 240-249.

Du Boulay, B. (1986). Some difficulties of learning to program. Journal of Educational Computing Research, 2(1), 57-73.

Ersoy, H. (2016). Durum çalışması. M. Y. Özden ve L. Durdu (Yay. haz.). Nitel Araştırma Yöntemleri içinde (ss. 3-18). Ankara: Anı Yayıncılık.

Graham, C.R., Burgoyne, N., Pamela Cantrell, Smith L., Clair L.S. ve Harris R. (2009). TPACK development in science teaching: Measuring the TPACK confidence of inservice science teachers. Tech Trends, 53(5), 70-79.

Guzdial, M. (2015). Learner-centered design of computing education: Research on computing for everyone. Synthesis Lectures on Human-Centered Informatics, 8(6), 1-165. doi: 10.2200/S00684ED1V01Y201511HCI033

Gülbahar, Y. (2017). Bilgi işlemsel düşünme ve programlama konusunda değişim ve dönüşümler. Y. Gülbahar (Yay. haz.), Bilgi İşlemsel Düşünmeden Programlamaya, içinde (ss. 395410). Ankara: Pegem Akademi.

Gültepe, A. (2018). Kodlama öğretimi yapan bilişim teknolojileri öğretmenleri gözüyle öğrenciler kodluyor. Uluslararası Liderlik Eğitimi Dergisi, 2(2), 50-60.

Harel, I. ve Papert, S. (1990). Software design as a learning environment. Interactive Learning Environments, 1(1), 1-32.

ISTE. (2011). Operational definition for computational thinking. Erişim adresi: https://id.iste.org/docs/ct-documents/computational-thinking-operational-definitionflyer.pdf.

Kafai, Y. B. ve Burke, Q. (2014). Connected code: Why children need to learn programming. MacArthur Foundation Series on Digital Media and Learning. MIT Press.

Kalelioglu, F., Gülbahar, Y. ve Kukul, V. (2016). A framework for computational thinking based on a systematic research review. Baltic Journal of Modern Computing, 4(3), 583.

Kalelioğlu, F. (2017). Bilgisayarsız bilgisayar bilimi (B3) öğretimi. Y. Gülbahar (Yay. haz.). Bilgi İşlemsel Düşünmeden Programlamaya, içinde (ss. 183-206). Ankara: Pegem Akademi.

Kandemir, C. M. (2017). Metin tabanlı programlama. Y. Gülbahar (Yay. haz.). Bilgi İşlemsel Düşünmeden Programlamaya, içinde (ss. 267-294). Ankara: Pegem Akademi.

Kert, S. B. (2018). Programlama öğretimi için pedagojik yaklaşımlar. Y. Gülbahar ve H. Karal (Yay. haz.). Kuramdan Uygulamaya Programlama Öğretimi, içinde (ss. 93-130). Ankara: Pegem Akademi.

Koehler, M. J. ve Mishra, P. (2008). Introducing TPCK. J. A. Colbert, K. E. Boyd, K. A. Clark, S. Guan, J. B. Harris, M. A. Kelly ve A. D. Thompson (Yay. haz.). Handbook of 
Technological Pedagogical Content Knowledge For Educators içinde (ss. 1-29). New York: Routledge.

Menekse, M. (2015). Computer science teacher professional development in the United States: a review of studies published between 2004 and 2014. Computer Science Education, 25(4), 325-350.

Nasser-Abu Alhija, F. ve Levi-Eliyahu, O. (2019). Modelling achievement in advanced computer science: the role of learner characteristics and perceived learning environment. Computer Science Education, 29(1), 79-102.

National Curriculum. (2017). National curriculum in England: computing programmes of study. Department for Education. Erişim adresi: https://www.gov.uk/government/publications/ national-curriculum-in-england-computing-programmes-of-study.

Papert, S. ve Harel, I. (1991). Situating constructionism. Constructionism, 36(2), 1-11.

Perkins, D. N. ve Salomon, G. (2012). Knowledge to go: A motivational and dispositional view of transfer. Educational Psychologist, 47(3), 248-258.

Robins, A., Rountree, J. ve Rountree, N. (2003). Learning and teaching programming: A review and discussion. Computer Science Education, 13(2), 137-172.

Salomon, G. ve Perkins, D. N. (1987). Transfer of cognitive skills from programming: When and how? Journal of educational computing research, 3(2), 149-169.

Sands, P., Yadav, A. ve Good, J. (2018). Computational thinking in K-12: In-service teacher perceptions of computational thinking. M. S. Khine (Yay. haz.), Computational thinking in the STEM disciplines, içinde (ss. 151-164). Cham: Springer.

Schreier, M. (2012). Qualitative content analysis in practice. Thousand Oaks, CA: Sage

Schwartz, J., Stagner, J. ve Morrison, W. (2006). Kid's programming language (KPL). In ACM SIGGRAPH 2006 Educators Program içinde (s. 52). ACM. DOI: 10.1145/1179295.1179348.

Selby, C. ve Woollard, J. (2013). Computational thinking: the developing definition. Erişim adresi: https://eprints.soton.ac.uk/356481/1/Selby_Woollard_bg_soton_eprints.pdf.

Shulman, L. (1986). Those who understand: Knowledge growth in teaching. Educational Researcher, 15(2), 4-14.

Şimşek, İ. B. (2018). Dünyada programlama öğretimi. Y. Gülbahar ve H. Karal (Yay. haz.), Kuramdan Uygulamaya Programlama Öğretimi, içinde (ss. 37-65). Ankara: Pegem Akademi.

Tebliğler Dergisi. (2016). 2709 Say1l Tebliğler Dergisi. Erişim adresi: http://goo.gl/uhnxt6.

Türker, P. M. ve Pala, F. K. (2018). Ortaokul öğrencilerinin, öğretmenlerin ve öğrenci velilerinin kodlamaya yönelik görüşleri. İlkögretim Online, 17(4).

Üçgül, M. (2017). Eğitsel robotlar ve bilgi işlemsel düşünme. Y. Gülbahar (Yay. haz.). Bilgi İşlemsel Düşünmeden Programlamaya, içinde (ss. 295-317). Ankara: Pegem Akademi.

Wing, J. M. (2006). Computational thinking. Communications of the ACM, 49(3), 33-35.

Wing, J. (2011). Research notebook: Computational thinking-What and why. The Link Magazine, 20-23.

Yadav, A., Krist, C., Good, J. ve Caeli, E. N. (2018). Computational thinking in elementary classrooms: measuring teacher understanding of computational ideas for teaching science. Computer Science Education, 28(4), 371-400.

Yecan, E., Özçınar, H. ve Tanyeri, T. (2017). Bilişim teknolojileri öğretmenlerinin görsel programlama öğretimi deneyimleri. İlkögretim Online, 16(1), 377-393.

Yıldırım, A. ve Şimşek, H. (2013). Sosyal bilimlerde nitel araştırma yöntemleri (9. Baskı). Ankara: Seçkin Yayıncılık.

Yin, R. K. (2003). Case study research: Design and methods (3rd ed.). Thousand Oaks, CA: Sage.

YÖK. (2018). Bilgisayar ve Öğretim Teknolojileri Öğretmenliği Lisans Programı. Erişim adresi: https://www.yok.gov.tr/Documents/Kurumsal/egitim_ogretim_dairesi/Yeni-OgretmenYetistirme-Lisans-Programlari/Bilgisayar_ve_Ogretim_ Teknolojileri_ Ogretmenligi_ Lisans_Programi.pdf. 
Yükseltürk, E. ve Altık, S. (2017). Blok tabanlı programlama. Y. Gülbahar (Yay. haz.). Bilgi İşlemsel Düşünmeden Programlamaya, içinde (ss. 241-266). Ankara: Pegem Akademi.

\section{Extended Abstract}

\section{Introduction}

Wing defined computational thinking with Cuny and Snyder as "the thought processes involved in formulating problems and their solutions so that the solutions are represented in a form that can be effectively carried out by an information-processing agent" (Cuny, Snyder \& Wing as cited in Wing, 2011). Following these definitions, Brennan and Resnick (2012) provided tripartite definition including computational concepts, computational practices and computational perspectives. Computational thinking and computing education are relatively new notions in educational research, and technologies that can be used to help students to learn computing, are changing rapidly. Computing teachers should get used to technological, pedagogical and content knowledge (TPACK) (Koehler \& Mishra, 2008) in this relatively new and rapidly changing field. TPACK of teachers can affect the quality of computing instruction. There is a need to describe the situation primarily from the teachers' point of view. Therefore, the aim of this study was to explore the opinions of information technology and software course teachers related to computing education.

\section{Method}

In this study, case study design was utilized (Yin, 2003). 22 information technology and software course teachers were purposefully selected from a city in the western Black Sea region. Qualitative interviews were conducted with each of the participants. A semi-structured interview protocol that was constructed by the researchers was utilized to handle the interviews. Content analysis (Cetin, 2016) was used to analyze the qualitative data.

\section{Results}

Results of the data analysis can be considered under five headings: Purpose of Computing, Fundamental Skills in Computing Education, Tools for Computing Education, CS Unplugged and Teacher Needs. The Purpose of Computing is related to the general aim of computing education. There are four categories under this heading: business oriented (14 participants), thinking skills (13 participants), instruction oriented (7 participants), and production oriented (6 participants). The participants gathered under business oriented category generally believed that the aim of the computing education is to satisfy the needs of the 21 . Century jobs and business. The participants under the thinking skills category generally contended that computing education should focus on developing students' thinking skills including analytical thinking, daily life problem solving, creativity and problem solving schemes. In contrast to the deepness of the participants' comments in the business-oriented category, the ones in the thinking skills category were superficial in terms of some skills. The participants in the next category, namely instruction oriented focused more on instructional aspect of computing education and contended that computing education should be authentic and can be used as an instructional technology for the subject domains. The last category is production oriented. Participants under this category stated that students should not be consumers; rather they need to produce something by using computing.

The second heading is Fundamental Skills in Computing Education. Since the categories under this heading is similar to the categories of Purpose of Computing, details of this heading will not be given considering the word limits. The third heading is Tools for Computing Education, which is an indication for the tool based instructional approach to computing education. First, 22 of the participants mentioned about block based programming environments and Scratch was the most popular example for such environments. The most popular reason of 
choosing block-based environments was their entertaining and attractive nature. Second, 9 of the participants mentioned about robotic environments. Arduino was the mostly mentioned kit among the others. Participants generally stated that students could see the results of their programs in a concrete way. Third, five of the participants considered 3D design software as a tool to teach computing. Tinkercad was found as the most popular software among the participants. Nevertheless, they did not explicitly mention how they can use those software tools to teach programming. Next, three of the participants considered text based environments as a tool to teach computing. Visual Basic, PHP and ASP were the examples given by participants for text-based tools. Fifth, two of the participants contended that mobile programming environments can be used to teach computing. These two participants stated that students are already living in a digital world including mobile platforms. Mobile platforms can be motivating them in computing education. Finally, only one of the participants mentioned about computer science unplugged by giving Lego as an example. However, the answer given by the participant is far away from the computer science unplugged literature.

The fourth heading is CS Unplugged. The findings refer that participants generally were not aware of the CS Unplugged approach and most of them stated that computing instruction cannot be done without using hardware and software. The last heading is called Teacher Needs. There are three categories under this heading (Pedagogy, Technology and Content Knowledge). Seven participants gathered under Pedagogy category. These participants stated that they did not get any pedagogy course specific to computing education during their undergraduate studies. There were seven participants under the Technology category. These participants stated that the technological tools that they were taught during their undergraduate years are too different than the tools that they need to teach in their computing classes. There were six participants under the Content Knowledge category. They contended that they do not have enough content knowledge related to computing.

\section{Discussion and Conclusion}

The results of this study showed that teachers provided enough explanations related to economic value of computing education while they seemed inadequate related to cognitive implications of it. The most popular tools to teach computing were block based and robotic tools. Teachers did not seem to be aware of the value of text based and CS Unplugged approaches. Moreover, they stated that they feel themselves inadequate in technology, pedagogy and content knowledge aspects of computing education. As a result, although many countries around the world have recently had special interest in computing education and they put computing related courses to their curriculum, the computing teachers who are in charge of teaching the subject may not be qualified enough to help students to have rich and deep experience related to computing education (Sands, Yadav and Good, 2018). This might negatively affect the future of computing education. 